Reprod. Nutr. Dévelop., 1985, 25 (5), 931-943.

\title{
The physiology of corticotropin-releasing factor (CRF)
}

\author{
Marie-Charles RAUX-DEMAY, F. GIRARD
}

Hopital Trousseau, 26, avenue du Dr A. Netter, 75012 Paris, France.

Summary. Corticotropin-releasing factor (CRF) was characterized, purified and synthesized in 1981 by Vale. The composition of this 41 amino-acid peptide varies slightly from one species to another. Its principal origin is the paraventricular nucleus of the hypothalamus and, by the portal vessels, it reaches the adenohypophysis where it stimulates the corticotrophs.

The effects of CRF have been analysed by in vitro and in vivo experiments. Some actions on the autonomic nervous system have been described. The action of CRF on adrenocorticotrophic hormone (ACTH) secretion is predominant, but it acts in relation with arginine-vasopressin and accessorily with angiotensin and catecholamines. Adrenal steroids act on feedback control of CRF secretion in the hypothalamus and also on pituitary corticotrophs.

The CRF function starts between the 16th and 19th day in the fetal rat. The placenta is able to produce CRF.

Hypothalamic regulation of adrenocorticotrophic hormone (ACTH) secretion in the anterior pituitary has been recognized since 1948 (Harris, 1948). Thereafter, hypothalamic extracts were seen to have CRF activity (Guillemin and Rosemberg, 1955) which since then has been shown to be polymorphic, i.e. shared by arginine vasopressin (AVP), angiotensin II (A II) and adrenaline. The purification of a molecule comprising 41 amino acids from half a million ovine hypothamami (oCRF) has opened up a vast potential field of research (Vale et al., 1981).

\section{Characterization of 1-41 CRF}

The purification of ovine CRF (oCRF) was rapidly followed by the determination of its primary structure and the synthesis of the molecule (Vale et al., 1981).

Both extracted and synthetic oCRF's were shown to increase the secretion of ACTH and $\beta$-endorphin in vitro in anterior pituitary cell culture and in vivo in rats, and the 10-fold higher activity of the synthetic molecule over natural oCRF has been attributed to the presence of an oxidized methionine residue at C21. oCRF 
has sequences in common with sauvagine, angiotensinogen and urotensin 1, and differs by 7 amino acids (Vale et al., 1983) from human CRF (hCRF) and rat CRF (rCRF) which are identical (table 1). The $9-41$ residue of oCRF retains $90 \%$ of the biological activity of the molecule, but alterations of the secondary structure result in antagonistic effects ( $\alpha$-helix 8-41) (Rivier, Rivier and Vale, 1984).

The cDNA of the oCRF precursor was cloned by Furutani et al., (1983) and led to the discovery of a 190 amino-acid CRF precursor protein with several potential cleavage sites and with structures similar to the precursors of neurophysin, AVP and pro-opio-melanocortin (POMC).

TABLE 1

Amino acid sequences of sheep CRF, rat CRF and human CRF.

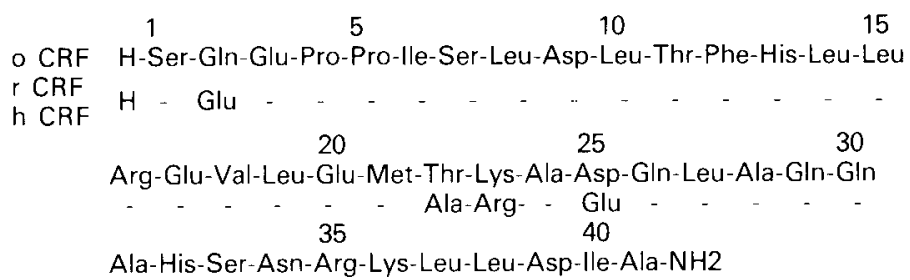

Met-Glu - Ile-NH2

\section{Location of CRF}

The CRF content of different tissues has been determined both by measurement of either CRF activity or CRF immunoreactivity in tissue extracts and by immunohistochemical techniques.

Immunohistological studies combined with electron microscopy have led to the location of CRF-secreting neuron bodies in the paraventricular and supraoptical nuclei and the lateral hypothalamus of rats. After a complex passage, the axons pass to the median eminence where positive reactions have been detected in the vicinity of the capillaries of the portal hypophysial plexus (Vigh et al., 1984).

However, endocerebral location of CRF is not restricted to the hypothalamus. CRF immunoreactivity has been found in the subcortical regions of the brain, in the medulla and in the cerebral cortex, suggesting its intervention in a number of regulatory mechanisms, particularly in the autonomic nervous system and in response to stress.

Suda et al., 1984 carrying out human post-mortem investigations, isolated a substance which was immunoreactive with the anti-hCRF antibody; the dilution curves of this isolated substance were parallel to the standard curves of rCRF in various tissues, including the hypothalamus, pituitary stalk and posterior pituitary. Among the extra-cerebral tissues, the adrenals were found to contain approximately $10 \%$ of the CRF concentration of the hypothalamus.

The highest levels of CRF were found in the pituitary stalk, and these levels rise with stress. In stressed rats, CRF concentions in the portal hypophysial 
capillary blood are between 300 and $500 \%$ more than those in the circulation (Gibbs and Vale, 1982).

This isolated substance thus satisfies the criteria for CRF activity which are production by the hypothalamus, transfer to the pituitary via the hypophysial portal system, pituitary stimulation of in vitro and in vivo production of ACTH and other POMC derivatives.

\section{Pharmacokinetics}

The results of studies of the disappearance of CRF from the blood after its injection into human subjects agree on the following points: the decrease of oCRF after IV injection follows a multi-sloped exponential curve, the first component having a half-life of 6 to $11 \mathrm{~min}$ and the second one 55 to $73 \mathrm{~min}$. The metabolic clearance rate (MCR) is between 95 to 150 liters $/ \mathrm{m} 2 / 24 \mathrm{~h}$ and the diffusion volume is about 6 liters (Nicholson et al., 1983). The hCRF profile is different. The drop occurs along a simple exponential curve with a half-life of $4 \mathrm{~min}$, a MCR of 50 liters/m2/24 h and a diffusion volume of 6 liters (Schurmeyer et al., 1984).

\section{Physiological effects}

CRF stimulation of ACTH production is well documented in vivo in humans and animals and in vitro in various types of human and animal anterior pituitary preparations under both normal and pathological conditions (Widmaier and Dallman, 1984). Stimulation is modulated by numerous factors which intervene either in the secretion of CRF itself or in its action on the anterior pituitary. Nevertheless, the effects of CRF are not limited to those on the anterior pituitary, and CRF is considered to be an important co-ordinator of the organism's response to stress.

\section{A) Stimulation of ACTH production and other POMC derivatives}

1) In animals :

a) In vitro. - The capacity to stimulate the production of POMC and its derivatives, ACTH, $\beta$-endorphin and $\beta$-lipotropin $(\beta$-LPH), by cultured anterior pituitary cells was one of the criteria used to monitor the steps in oCRF purification (Vale et al., 1981). Half-maximal response was obtained in this system with between 50 and 200 pmoles of synthetic OCRF, a dose which was then used in further stimulation experiments.

In vitro stimulatory activity has also been studied in other systems like pituitary fragments in perifusion (Widmaier and Dallman, 1984), in culture (Buckingham, 1982), and in pituitary cells suspended in columns (Gaillard et al., 1984). Sensitivity varies but the in vitro effect appears to be specific for POMC derivatives (Wehrenberg et al., 1984). Moreover, the action of CRF does not appear to affect ACTH production in the intermediate lobe (Suda et al., 1983). 
b) In vivo. - Various types of injections in rats result in a stimulation of adrenal-pituitary function. A single IV injection of 0.3 nanomole of oCRF induces an immediate $(5 \mathrm{~min}$ ) rise in ACTH level which returns to base-line within $2 \mathrm{~h}$ and in the corticosterone and progesterone levels which rise within $10 \mathrm{~min}$ and return to base-line levels in $6 \mathrm{~h}$ (Rivier and Vale, 1984a). Repeated oCRF injections at 2hour intervals lead to a long desensitization phase of about $12 \mathrm{~h}$, after which normal sensitivity reappears in spite of elevated corticosterone levels. Intravenous perfusion has similar effects (Rivier and Vale, 1984a). However, if the animal is pretreated with anti-CRF antibody, no such increase occurs (Rivier and Vale, 1982).

The perfusion of oCRF (10 or $50 \mathrm{ng} / \mathrm{min}$ ) over a period of $48 \mathrm{~h}$ induces a secretory state in the anterior pituitary of rats, i.e. the number of corticotropic cells decreases but their surface area increases. This is identical to the response to bilateral adrenalectomy (Westlund, Aguilera and Childs, 1985).

\section{2) In humans:}

The intravenous injection of oCRF 10.3 to $30 \mu \mathrm{g} / \mathrm{kg})$ induces an increase in the levels of ACTH and cortisol with the lowest dose $10.3 \mu \mathrm{g} / \mathrm{kg}$ ) on upwards. With doses above $3 \mu \mathrm{g} / \mathrm{kg}$, the response becomes biphasic with an early peak after $15 \mathrm{~min}$, followed by a slight decrease and a second peak, then a return to base-line levels after $6 \mathrm{~h}$. These doses $(3$ to $30 \mu \mathrm{g} / \mathrm{kg})$ are also accompanied by secondary effects such as flushes and dyspnoea which may persist for several hours. When these higher doses are injected late in the afternoon the normallyobserved nocturnal peak disappears (DeBold et al., 1983). A dose of $30 \mu \mathrm{g} / \mathrm{kg}$ of oCRF, the only dose tested, is also capable of increasing the levels of LPH $(\beta+\gamma)$ and $\beta$-endorphin ( $\beta$-endorphin $+\beta$-LPH) (Jackson et al., 1984); these tests were done in the late afternoon.

The magnitude of $\mathrm{ACTH}$ and cortisol responses to total doses of $100 \mu \mathrm{g}$ (Tsukada et al., 1983) or $50 \mu \mathrm{g}$ (Copinschi et al., 1983) appears to be identical in the morning and evening. Stimulation by hCRF is more short-lived and less intense (Schurmeyer et al., 1984). oCRF has been seen to have a stimulatory effect on fragments of human anterior pituitary tissue in superfusion with a sensitivity of $1 \mathrm{nM}$ for corticotropic adenomas and of $0.1 \mathrm{nM}$ for the adjacent tissue (Suda et al., 1984).

\section{3) Mechanism of CRF action within the anterior pituitary}

In rats decapitated $2 \mathrm{~min}$ after the injection of 125 -oCRF, radioactivity is found near the plasma membranes of $9 \%$ of the anterior pituitary cells and exclusively among the corticotropic cells. After 8 and $15 \mathrm{~min}$, the radioactivity migrates towards the Golgi apparatus and the lysosomes. This internalization is thought to play a role in CRF breakdown. All the labelled molecules disappear within $30 \mathrm{~min}$ (Leroux and Pelletier, 1984).

The effects of CRF are mediated by the activation of adenyl cyclase. CAMP is increased within the cells and in culture media (Labrie et al., 1984), the CRF effect is duplicated by $8 \mathrm{Br}$. cAMP (Giguere, 1982) and amplified by GTP (Labrie et al., 
1984) and phosphodiesterase inhibitors (Aguilera et al., 1983, Vlaskovska et al., 1984).

Finally, CRF stimulates the transcription of the CDNA for POMC which is increased by a factor of 10 in both the anterior $(1 \mathrm{nM})$ and the intermediate (10 nM) lobes (Eberwine et al., 1984).

The CRF receptors in the anterior pituitary have the following characteristics (Wynn et al., 1983); high affinity, $\mathrm{Kd}=10^{-9} \mathrm{M}$, low capacity, specificity and reversibility. The number of sites changes with the adrenal status. CRF injection may induce a period of desensitization both in vitro (Reisine and Hoffman, 1983) and in vivo (Rivier and Vale, 1984a).

\section{B) Other effects of CRF}

These data have been obtained mainly from experiments on animals and concern large-scale changes in the intracerebral concentrations of CRF. The presence of the pituitary gland is not essential.

1) Effects on the autonomic nervous system. - Intracerebro-ventricular injection of oCRF into rats results in increased blood pressure and heart rate, effects which are totally inhibited by chlorisondamine, an inhibitor of sympathetic ganglions (Fisher et al., 1982). A rise in glycemia and in the plasma levels of adrenaline and noradrenaline was also observed (Brown et al., 1982). Bilateral adrenalectomy and chlorisondamine abolish these effects, but hypophysectomy does not. The intermediary in these effects of CRF therefore seems to be the activation of the peripheral sympathetic nervous system and, more particularly, the adrenal medulla. A similar type of action is the inhibition of pentagastrin induced gastric acidity (Tache et al., 1983).

2) Effects on other hypothalamic factors. - Intracisterno-ventricular injection in rats also results in a decrease in circulating GH (Rivier and Vale, 1984c), probably via a stimulation of somatostatin. In gonadectomized rats, the results are diminished base-line levels of LH. These effects are not counteracted by blockage of the sympathetic ganglions or by dexamethasone or naltrexone, and they do not apply to $\mathrm{LH}$ stimulation by $\mathrm{GnRH}$. In intact female rats, intraventricular injection of CRF blocks $50 \%$ of the ovulations and $40 \%$ of the gestations (Rivier and Vale, 1984c).

3) Effects on behaviour. - Finally, central injections of oCRF induce increased activity and emotivity (Sutton et al., 1982).

\section{C) Relationship between CRF and response to stress.}

Several arguments support the notion that stress is a stimulatory factor in the production of CRF. Pre-treatment of rats with anti-CRF antibody partially suppresses the ACTH increases induced by various types of stress such as ether anesthesia (Rivier and Vale, 1982) or suspension by the tail (Westlund, Aguilera 
and Childs, 1985). Stress due to blood loss increases the flow of CRF into the hypophysial portal system (Plotsky and Vale, 1984) which can be inhibited by paraventricular nucleus infiltration using procaine. In turn, the CRF induces a number of physiological reactions which form a part of the stress response or its modulation: ACTH and endorphin secretion are stimulated; the peripheral adrenal system is stimulated; $\mathrm{GH}$ production (a typical stress response in rats) and $\mathrm{LH}$ production are depressed and, finally, behaviour is altered (table, 2).

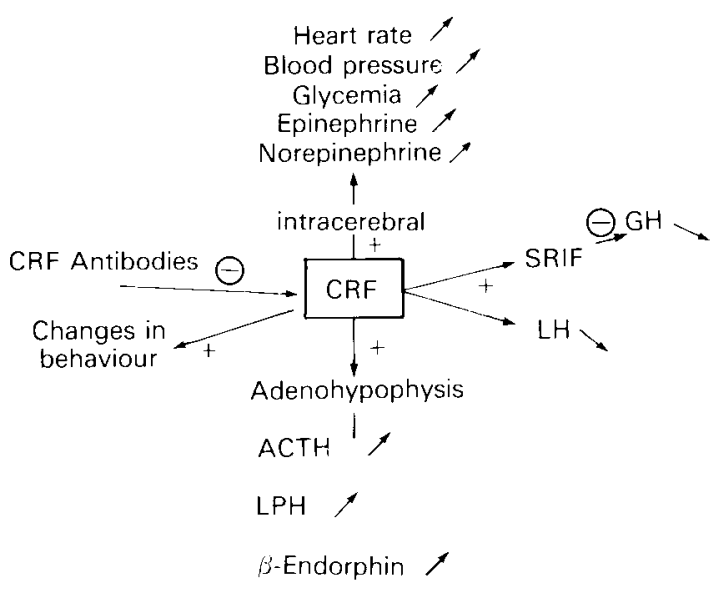

TABLE 2 CRF: Response to stress.

\section{Regulation of secretion : Relationships with other ACTH regulators.}

Numerous substances intervene in the regulation of CRF production by the hypothalamus or interfere with its stimulatory effect on the anterior pituitary. Some act at both levels and their actions sometimes counteract each other.

\section{A) CRF-arginine-vasopressin (VP) relationships}

1) Interactions between VP and CRF -induced ACTH stimulation. - Several substances, and in particular vasopressin, oxytocin and angiotensin II, are known for their stimulatory action on ACTH secretion both in vivo and in vitro. Nevertheless the synergistic effects of these peptides with those of CRF appear to be essential. In isolated anterior pituitary cells, first VP, then CRF, and then a combination of VP and CRF progressively stimulate ACTH secretion. The combined stimulation is greater than the sum of the two individual effects. Median eminence extracts have a slightly lower stimulatory capacity than the VPCRF combination, but greater than CRF alone (Gillies, Linton and Lowry, 1982). CRF activity is diminished through the presence of anti-VP antibodies. It is low in hypothalamic extracts from Brattleboro rats. In vivo a similar synergistic action 
has been observed in man (Liu et al., 1983) and in animals (Rivier et al., 1984a) where it is inhibited by pretreatment with either anti-CRF or anti-VP antibodies or both (Gillies, Linton and Lowry, 1984). The mechanisms of this synergetic action remain to be discovered. The direct action of VP on ACTH production is not accompanied by any stimulation of cAMP production, whereas the combination of CRF-AVP has a synergistic stimulatory effect on intracellular cAMP (Aguilera et al., 1983 ; Giguere and Labrie, 1982).

Experiments with VP antagonists, (anti-receptors of antidiuretic activity, mediated by adenyl cyclase $\left(V_{2}\right)$ and anti-receptors of vasopressin activity $\left(V_{1}\right)$ independently of adenyl cyclase) have provided data in favour of VP action on the anterior pituitary via $V_{1}$-type receptors; the blockage of these receptors by specific antagonists inhibits the synergistic action of CRF-VP (Rivier et al., 1984a). Nevertheless, a third type of receptor $\left(V_{3}\right.$ ?) may be implicated (Baertschi and Friedli, 1985).

There is evidence that the specific nature of VP receptors in the anterior pituitary may undergo down-regulation and desensitization (Koch and LutzBucher, 1985 ; Gaillard et al., 1984).

2) Interactions between VP and hypothalamic CRF production. - Plotzky, Bruhn and Vale (1984) observed a $90 \%$ decrease in portal CRF levels following central injection of AVP into rats. A similar injection of either anti-AVP antibodies or an AVP antagonist also increases portal CRF levels as well as plasma ACTH levels. However, under certain circumstances, VP has been seen to be involved in the stimulation of CRF secretion.

\section{B) CRF relationships with other non-steroid regulators}

1) Peptide factors. - The action of angiotensins II and III on the anterior pituitary appears to be similar to that of VP: its intrinsic activity is weak; it is additive to that of CRF in vivo and in vitro; it is independent of adenyl cyclase activity, mediated by specific receptors and inhibited by saralasine, and it is specific (angiotensin I is inactive in the presence of captopril) (Aguilera et al., 1983 ; Spinedi and Negro-vilar, 1983). It is nevertheless not impossible that the additive action of All on ACTH production has a central pathway (in contrast with those of CRF and VP) since it disappears in animals pretreated with chlorpromazine, morphine and nembutal (Spinedi and Negro-Vilar, 1983).

A similar synergistic action is exhibited by $\mathrm{PH} \mathrm{I}_{27}$, a peptide of 27 amino acids having a structure similar to that of VIP (Tilders, Tatemoto and Berkenbosch, $1984)$; this peptide is immunohistochemically detectable in several hypothalamic nuclei. Certain neurons found in these nuclei may simultaneously contain $\mathrm{PH} \mathrm{I}_{27}$ and CRF-like and enkephalin-like substances (Hokfelt et al., 1983). Other hypothalamic peptides ( $\mathrm{LHRH}, \mathrm{GRH}, \mathrm{TRH}$ ) have neither an isolated effect on ACTH production nor a synergistic action with CRF in vivo or in vitro (Wehrenberg et al., 1984).

2) Catecholamines. - Immunocytochemical studies have shown (Mezey et al., 1984) that endocerebral adrenaline decreases the production of CRF; this 
contrasts with its action on the pituitary whereby ACTH secretion is stimulated via $\alpha_{1}$ receptors (Labrie et al., 1984) and there is an additive effect on CRF action (Giguere and Labrie, 1983). In turn, CRF stimulates the secretion of both noradrenaline and adrenaline (Brown, Rivier, and Vale, 1984).

3) Prostaglandins. - In vitro stimulation of ACTH production by rat pituitary glands (CRF and AVP) is accompanied by increased $P G E_{2}$ concentration in the culture medium. The inhibition of $\mathrm{PGE}_{2}$ production with indomethacin increases anterior pituitary response, and $\mathrm{PGE}_{2}$ production is thought to act as a negative feedback modulator (Vlaskovska, Hertting and Keppel, 1984).

\section{C) Interactions with steroids}

1) Interactions between steroids and hypothalamic CRF production. Glucocorticoid feedback control of ACTH secretion is well documented but the site of this action remains unknown. Much of the discussion arises from differences in the means of evaluating hypothalamic and anterior pituitary contents, and interpretations can be ambiguous. Some workers have seen decreases in CRF activity in hypothalamic extracts (biological assay) 8 days after adrenalectomy in rats (Hashimoto et al., 1981) accompanied by increases in both pituitary and plasma ACTH levels. Other workers have reported changes varying with time (an initial decrease followed by an increase during the second week) in the CRF content of the median eminence (radioimmunoassay) and the ACTH content of the anterior pituitary (Suda et al., 1983).

Nevertheless, certain data argue in favour of the hypothalamus as one of the sites of feedback control :

- ACTH elevation in response to bilateral adrenalectomy is diminished in rats pretreated with anti-CRF antibodies (Rivier and Vale, 1982);

- in rats pretreated with dexamethasone, there is a reduction in the flow of CRF in the portal system, stimulated by stress-induced hemorrhage (Plotzky and Vale, 1984).

Decreases in the CRF content of the hypothalamus are attributed to « initial depletion ", followed by a phase of synthesis. In contrast, glucocorticoid treatment results in increases in hypothalamic CRF content, whereas androgens and progesterone have no effect. Aldosterone has a weak glucocorticoid action and oestrogens have a mild stimulatory effect (Buckingham, 1982).

2) Interactions between steroids and CRF effects on the pituitary gland. - In vivo experiments: in rats dexamethasone treatment causes a drop and adrenalectomy a rise in ACTH levels in the anterior pituitary (Hashimoto et al., 1981).

In vitro experiments: ACTH stimulation induced by the action of 2 nmoles of CRF on rat anterior pituitary gland in perifusion is inhibited by $\left(10^{-6} \mathrm{M}\right)$ dexamethasone and $\left(10^{-7} \mathrm{M}\right)$ cortisol and corticosterone. The time-lag of this inhibition is 10 min which is longer than the 3-min rapid feedback observed in vivo (Widmaier and Dallman, 1984). 
It therefore seems certain that glucocorticoids inhibit CRF-stimulated ACTH production in the anterior pituitary gland, but their mode of action is not clearly understood. It may be independent of adenyl cyclase activation (Giguere et al., 1982) or related to the suppression of this stimulation (Bilezikjian and Vale, 1983).

\section{D) Regulation of CRF-ACTH response to stress}

Various relationships have been studied under different stress conditions. The injection of anti-CRF antibodies into rats results in only an $80 \%$ suppression of the ACTH response to stress. Specific $V_{1}$ antagonists of vasopressin activity affect their suppression either only after $10 \mathrm{~min}$ (ether stress) (Rivier and Vale, 1983) or not at all (« psychological " stress) (Mormède, 1983). The depression of circulating catecholamines results in about a $50 \%$ inhibition of the stress response. For total inhibition, the anti-CRF antibodies need to be associated with either a VP antagonist or an inhibitor of catecholamine production (Rivier and Vale 1983). Dexamethasone also inhibits this response. All these findings demonstrate the multi-faceted nature of ACTH stimultion in response to stress.

\section{Ontogeny}

The ontogeny of CRF production and its activity have been studied in various fetal animals, including man.

The rat fetus. - The corticotropic cells of the pars distalis appear around day 15 or 16 of gestation and precede hypothalamic CRF production which begins around day 18 and appears in the pituitary stalk on day 20 (Bugnon et al., 1982). The presence of the hypothalamus does not seem to be indispensable to corticotropic cell development since encephalectomy at either day 16 or 19 has no effect on pituitary ACTH content. However, the release of ACTH is altered, the plasma levels of ACTH drop and the adrenals atrophy (Chatelain and Dupouy, 1981). It is noteworthy that decapitation of the fetus on either of these days results in a massive decrease in plasma ACTH levels. In fetal pituitary cultures tested at days 17, 19 and 21, pituitary ACTH progressively increase as does ACTH release into the medium.

These same pituitary preparations show age-related sensitivity to stimulation by AVP, CRF and AVP-CRF combinations, whereas corticosterone induces about a $50 \%$ inhibition of base-line production (Dupouy and Chatelain, 1984).

The ovine fetus. - Time-course studies troughout gestation indicate increases in base-line plasma ACTH levels from day 120, about the time CRF reactivity appears; these levels increase to a maximum close to term (Wintour et al., 1984).

The human fetus. - In vitro investigations have provided some physiological data. With oCRF $(20 \mu \mathrm{g})$ stimulation of anterior pituitary glands in perifusion the response (the release of endorphin and LPH) is observed after only 20 weeks of pregnancy. No $\alpha-\mathrm{MSH}$ is detectable and intermediate lobe fragments are 
insensitive to CRF, whereas all fragments are stimulated by the depolarizing action of $10^{-6} \mathrm{M} \mathrm{KCl}$ (Gibbs et al., 1982).

It is worth mentioning that the placenta contains a CRF-like substance with a bioactivity on anterior pituitary cells parallel to that of oCRF and median eminence extracts (Shibasaki et al., 1982). A similar substance is also found in the plasma of pregnant women during the last 3 months of pregnancy (Sasaki et al., 1984). The influence of placental CRF on the adrenal-pituitary function remains to be determined. At term, CRF levels are higher in maternal plasma and in cord venous blood than in arterial blood, suggesting a transfer from the mother to the fetus (Campbell et al., 1985).

Réunion d'Endocrinologie de l'Association des Physiologistes, Clermont, 23-24 Avril 1985.

\section{Résumé. Physiologie de la corticolibérine (CRF).}

La corticolibérine (corticotropin-releasing factor, CRF) a été caractérisée, purifiée et synthétisée en 1981 par Vale. II s'agit d'un peptide de 41 acides aminés dont la composition peut être légèrement différente d'une espèce à l'autre. Sa source principale est le noyau paraventriculaire de l'hypothalamus. II est conduit par le système des vaisseaux porte à l'antéhypophyse où il exerce ses effets sur les cellules corticotropes. Les effets du CRF ont été analysés au cours d'expériences in vitro et in vivo. Certains effets sur le système nerveux autonome ont été décrits. Néanmoins l'action du CRF sur la sécrétion de I'ACTH est prédominante; elle se fait en relation avec celle de l'arginine vasopressine et plus accessoirement avec l'angiotensine et les catécholamines. Les stéroides surrénaux exercent leur rétro-contrôle à la fois sur la sécrétion du CRF au niveau de l'hypothalamus et sur son action sur les cellules corticotropes. La fonction CRF s'établit vers le 16-19ème jour chez le foetus de Rat. Le placenta est susceptible de produire du CRF.

\section{References}

AGUILERA G., HARWOOD J. P., WILSON J. X., MORELL J., BROWN J. H., CATT K. J., 1983. Mechanisms of action of corticotropin-releasing factor and other regulators of corticotropin release in rat pituitary cells. J. Biol. Chem, 258, 8039-8045.

BAERTSCHI J., FRIEDLI M. 1985. A novel type of vasopressin receptor on anterior pituitary corticotrophs? Endocrinology, 116, 499-502.

BILEZIKJIAN L. M., VALE W., 1983. Glucocorticoids inhibit corticotropin-releasing factor induced production of adenosine $3^{\prime}, 5^{\prime}$-monophosphate in cultured anterior pituitary cells. Endocrinology, 113, 657-662.

BROWN M. R., FISHER L. A., SPIESS J., RIVIER C., RIVIER J., VALE W., 1982. Corticotropinreleasing factor: Actions on the sympathetic nervous system and metabolism. Endocrinology, 111, 928-931.

BROWN M. R., RIVIER C., VALE W, 1984. Central nervous system regulation of adrenocorticotropin secretion : role of somatostatins. Endocrinology, 114, 1546-1549.

BUCKINGHAM J. C., 1982. Effects of adrenocortical and gonadal steroids on the secretion in vitro of corticotrophin and its hypothalamic releasing factor. $J$. Endocr., 93, 123-132.

BUGNON C., FELLMANN D., GOUGET A., CARDOT J., 1982. Ontogeny of the corticoliberin neuroglandular system in rat brain. Nature, 298, 159-161.

CAMPBELL E. A., HALPIN D. M. G., PRICE J., DORNHOSST A., GILLHAM B., JONES M. T., 1985. Corticotrophin-releasing factor-like material in maternal plasma and venous and arterial cord plasma. 4th joint-meeting of Brit. endoc. Soc. J. Endocr., 104, suppl. 65.

CHATELAIN A., DUPOUY J. P., 1981. Activity of the pituitary-adrenal system in rat fetuses 
subjected to encephalectomy in early or late stages of pregnancy. Neuroendocrinology, 33 , $148-152$.

COPINSCHI G., BEYLOOS M., BOSSON D., DESIR D., GOLSTEIN J., ROBYN C. LINKOWSKI P., MENDLEWICS J., FRANCKSON J. R. M., 1983. Immediate and delayed alterations of adrenocorticotropin and cortisol nycthemeral profiles after corticotropin releasing factor in normal man. J. clin. Endocrinol Metab., 57, 1287-1291.

DeBOLD C. R., DeCHERNEY G. S., JACKSON R. V., SHELDON W. R., ALEXANDER A. N., ISLAND D. P., VALE W., ORTH D. N., 1983. Effect of synthetic ovine corticotropinreleasing factor : Prolonged duration of action and biphasic response of plasma adrenocorticotropin and cortisol. J. clin. Endocrinol. Metab., 57, 294-298.

DUPOUY J. P., CHATELAIN A., 1984. In vitro effects of corticosterone, synthetic ovine corticotrophin-releasing factor and arginine vasopressin on the release of adrenocorticotrophin by fetal rat pituitary glands. J. Endocr., 101, 339-344.

EBERWINE J. H., JONASSEN J., EVINGER M. J., ROBERTS J. L., 1984. Regulation of POMC gene expression by $\mathrm{CRH}$ and glucocorticoids in primary rat pituitary cultures. 7 th $/ \mathrm{nt}$. Congr. Endocrinol, Quebec July 1-7. Abstract No 684.

FISHER L. A., RIVIER J., RIVIER C., SPIESS J., VALE W., BROWN M. R., 1982. Corticotropinreleasing factor (CRF) : central effects on mean arterial pressure and heart rate in rats. Endocrinology, 110, 2222-2224.

FURUTANI Y., MORIMOTO Y., SHIBAHARA S., NODA M., TAKAHASHI H., HIROSE T., ASAI M., INAYAMA S., HAYASHIDA H., MIYATA T., NUMA S., 1983. Cloning and sequence analysis of cDNA for ovine CRF precursor. Nature, 301, 537-540.

GAILLARD R. C., SCHOENENBERG P., FAVROD-COUNE C. A., MUlleR A. F., MARIE J., BOCKAERT J., JARD S., 1984. Properties of rat anterior pituitary vasopressin receptors : relation to adenylate cyclase and the effect of corticotropin-releasing factor. Proc. nat. Acad. Sci. U.S.A., 81, 2907-2911.

GIBBS D. M., STEWART R. D., LIU J. H., VALE W., RIVIER J., YEN S. S. C., 1982. Effects of synthetic corticotropin-releasing factor and dopamine on the release of immunoreactive $\beta$ endorphin/ $\beta$-lipotropin and $\alpha$-melanocyte-stimulating hormone from human fetal pituitaries in vitro. J. clin. Endocrinol. Metab., 55, 1149-1152.

GIBBS D. M., VALE W., 1982. Presence of corticotropin releasing factor-like immunoreactivity in hypophysial portal blood. Endocrinology, 111, 1418-1420.

GIGUERE V., LABRIE F., 1982. Vasopressin potentiates cyclic AMP accumulation and ACTH release induced by corticotropin-releasing factor (CRF) in rat anterior pituitary cells in culture. Endocrinology, 111, 1752-1754.

GIGUERE V., LABRIE F., 1983. Additive effects of epinephrine and corticotropin-releasing factor (CRF) on adrenocorticotropin release in rat anterior pituitary cells. Biochem. biophys. Res. Communic. 110, 456-462.

GIGUERE V., LABRIE F., COTE J., COY D. H., SUEIRAS-DIAZ J., SCHALLY A. V., 1982. Stimulation of cyclic AMP accumulation and corticotropin release by synthetic ovine corticotropinreleasing factor in rat anterior pituitary cells : site of glucocorticoid action Proc. nat. Acad. Sci. USA, 78, 3466-3469.

GILLIES G. E., LINTON E. A., LOWRY P. J., 1982. Corticotropin releasing activity of the new CRF is potentiated several times by vasopressin. Nature, 299, 355-357.

GILLIES G., LINTON E., LOWRY P., 1984. Vasopressin and the 41-amio acid corticotropin releasing factor involvement in the control of corticotropin secretion. In F. LABRIE, L. PROULX, Endocrinology, Elsevier Publ. Amsterdam, 955-958.

GUILLEMIN R., ROSENBERG B., 1955. Humoral hypothalamic control of anterior pituitary : study with combined tissue cultures. Endocrinology, 57, 599-607

HARRIS G. W., 1948. Neural control of the pituitary gland. Physiol. Rev. 28, 139.

HASHIMOTO K, UYNOKI S., KAGEYAMA J., OHNO N., TAKAHARA J., OFUJI T., 1981. Vasopressin and CRF-ACTH in adrenalectomized and dexamethasone-treated rats. Neuroendocrinology, 32, 87-91.

HOKFELT T., FAHRENKRUG J., TATEMOTO K., MUTT V., WERNER S., HULTING A. L., TERENIUS L., CAHNG K. J., 1983. The PHI (PHI-27)/corticotropin-releasing factor/ enkephalin immunoreactive hypothalamic neuron : possible morphological basis for integra- 
ted control of prolactin, corticotropin, and growth hormone secretion. Proc. nat. Acad. Sci. USA, 80, 895-898.

JACKSON R. V., DeCHERNEY G. S., DeBOLD C. R., SHELDON W. R., ALEXANDER A. RIVIER J., VALE W., ORTH D. N., 1984. Synthetic ovine corticotropin-releasing hormone: Simultaneous release of proopiomelanocortine peptides in man. J. clin. Endocrinol. Metab, 58, 740747.

KOCH B., LUTZ-BUCHER B., 1985. Specific receptors for vasopressin in the pituitary gland : evidence for down-regulation and desensitization to adrenocorticotropin-releasing factors. Endocrinology, $116,671-676$.

LABRIE F., GIGUERE V., PROULX L., LEFEVRE G., 1984. Interactions between CRF, epinephrine, vasopressin and glucocorticoids in the control of ACTH secretion. J. Steroid Biochem., 20, 153-160.

LEROUX P., PELLETIER G., 1984. Radioautographic study of binding and internalization of corticotropin-releasing factor by rat anterior pituitary corticotrophs. Endocrinology, 114, 14-21.

LIU J. H., MUSE K., CONTRERAS P., GIBBS D., VALE W., RIVIER J., YEN S. S. C. 1983. Augmentation of ACTH-releasing activity of synthetic corticotropin releasing factor (CRF) by vasopressin in women. J. clin. Endocrinol. Metab., 57, 1087-1089.

MEZEY E., KISS J. Z., SKIRBOLL L. R., GOLDSTEIN M., AXELROD J. 1984. Increase of corticotropin-releasing factor stainong in rat paraventricular nucleus neurones by depletion of hypothalamic adrenaline. Nature, 310, 140-141.

MORMĖDE P., 1983. The vasopressin receptor antogonist dPTyr (Me) AVP does not prevent stress-induced ACTH and corticosterone release. Nature, 302, 345-346.

NICHOLSON W. E., DeCHERNEY G. S., JACKSON R. V., DeBOLD C. R., UDERMAN H. ALEXANDER A. N., RIVIER J., VALE W., ORTH D. H., 1983. Plasma distribution, disappearance half-time, metabolic clearance rate and degradation of synthetic ovine corticotrophin-releasing factor in man. J. clin. Endocrinol. Metab., 57, 1263-1269.

PLOTSKY P. M., BRUHN T. O., VALE W., 1984. Central modulation of immunoreactive corticotropin-releasing factor secretion by arginine vasopressin. Endocrinology, 115, 1639-1641.

PLOTSKY P. M., VALE W., 1984. Hemorrhage-induced secretion of corticotropin-releasing factorlike immunoreactivity into the rat hypophysial portal circulation and its inhibition by glucocorticoids. Endocrinology, 114, 164-169.

REISINE T., HOFFMAN A., 1983. Desensitization of corticotropin-releasing factor receptors. Biochem biophys. Res. Communic. 111, 919-925.

RIVIER C., RIVIER J., MORMĖDE P., VALE W., 1984. Studies of the nature of the interaction vasopressin and corticotropin-releasing factor on adrenocorticotropin release in the rat. Endocrinology, 115, 882-886.

RIVIER J., RIVIER C., VALE W., 1984. Synthetic competitive antagonists of corticotropin-releasing factor : effect on ACTH secretion in the rat. Science, 224, 889-891.

RIVIER C., VALE W., 1982. Inhibition of adrenocorticotropic hormone secretion in the rat by immunoneutralization of corticotropin-releasing factor. Science, 218. 377-379.

RIVIER C., VALE W., 1983. Modulation of stress-induced ACTH release by corticotropin-releasing factor, catecholamines and vasopressin. Nature, 305, 325-327.

RIVIER C., VALE W., 1984a. Effect of corticotropin-releasing factor (CRF) on some endocrine functions. In F. LABRIE, L. PROULX. Endocrinology. Elsevier Publ. Amsterdam, 959-962.

RIVIER C., VALE W., 1984b. Influence of corticotropin-releasing factor on reproductive functions in the rat. Endocrinology, 114, 914-921.

RIVIER C., VALE W., 1984c. Corticotropin-releasing factor (CRF) acts centrally to inhibit growth hormone secretion in the rat. Endocrinology, 114, 2409-2411.

SAFFRAN M., SCHALLY A. V., 1955. The release of corticotrophin by anterior pituitary tissue in vivo. Can. J. Biochem. Physiol., 33, 408.

SASAKI A., LIOTTA A. S., LUCKEY M. M., MARGIORIS A. N., SUDA T., KRIEGER D. T., 1984. Immunoreactive corticotropin-releasing factor is present in human maternal plasma during the third trimester of pregnancy. J. clin. Endocrinol. Metab., 59, 812-814.

SCHULTE H. M., CHROUSOS G. P., BOOTH J. D., OLDFIELD E. H., GOLD P. W., CUTLER G. B., Jr., LORIAUX D., 1984. Corticotropin-releasing factor: pharmacokinetics in man. $J$. clin. Endocrinol. Metab., 58, 192-196. 
SCHURMEYER A. H., AVGERINOS P. C., GOLD P. W., GALLUCCI W. T., TOMAI T. P., CUTLER G. F., LORIAUX D. L., CHROUSOS G. P., 1984. Human corticotropin-releasing factor in man: Pharmacokinetic properties and dose-response of plasma adrenocorticotropin and cortisol secretion. J. clin. Endocrinol. Metab., 59, 1103-1108.

SHIBASIKI T., ODAGIRI E., SHIZUME K., LING N., 1982. Corticotropin-releasing factor-like activity in human placental extracts. J. clin. Endocrinol, Metabol., 55, 384-386.

SPINEDI E., NEGRO-VILLAR A., 1983. Angiotensin || and ACTH release: site of action and potency relative to corticotropin releasing factor and vasopressin. Neuroendocrinology, 37. 446-453.

SUDA T., TOMORI N., TOZAWA F., MOURI T., DEMURA H., SHIZUME K., 1983. Effects of bilateral adrenalectomy on immunoreactive corticotropin-releasing factor in the rat median eminence and intermediate-posterior pituitary. Endocrinology, 113, 1182-1184.

SUDA T., TOMORI N., TOZAWA F., DEMURA H., SHIZUME K., 1984a. Effects of corticotropinreleasing factor and other materials on adrenocorticotropin-secretion from pituitary glands of patients with Cushing's disease in vitro. J. clin. Endocrinol. Metab., 59, 840-845.

SUDA T., TOMORI N., TOZAWA F., MOURI T., DEMURA H., SHIZUME K., 1984b. Distribution and characterization of immunoreactive corticotropin-releasing factor in human tissues. $J$. clin. Endocrinol. Metab., 55, 861-866.

SUTTON R. E., KOOB G. F., LE MOAL M., RIVIER J., VALE W., 1982. Corticotropin-releasing factor produces behavioural activation in rats. Nature, 297, 331-333.

TACHE Y., GOTO Y., GUNION M. U., VALE W., RIVIER J., BROWN M., 1983. Inhibition of gastric acid secretion in rats by intracerebral injection of corticotropin releasing factor. Science, 222, 935-937.

TILDERS F., TATEMOTO K., BERKENBOSH F., 1984. The intestinal peptide PH 1-27 potentiates the action of corticotrophin-releasing factor on ACTH release from rat pituitary fragments in vitro. Endocrinology, 115, 1633-1635.

TSUKADA T., NAKAI Y., KOH T., TSUJII S., IMURA H., 1983. Plasma adrenocorticotrophin and cortisol responses to intravenous injection of corticotropin releasing factor in the morning and evening. J clin. Endocrinol. Metab., 57, 869-871.

VALE W., SPIESS J., RIVIER C., RIVIER J. 1981. Characterization of a 41-residue ovine hypothalamic peptide that stimulates secretion of corticotropin and $\beta$-endorphin. Science, 213, 13941397.

VALE W., RIVIER C., BROWN M. R., SPIESS J., KOOB G., SWANSON L., BILEZIKJIAN L., BOLLM F., RIVIER J., 1983. Chemical and biological characterization of corticotropin releasing factor. Recent Progr. Horm. Res. 39, 245-270.

VIGH S., MECHENTHALER I., TORRES-ALMEAN I., SUERAS-DIAZ J., COY D. H., CARTER W. H. PETRUSZ P. SCHALLY A. V., 1982. Corticotropin releasing factor (CRF): Immunocytochemical localization and radioimmunoassay (RIA). Life Sci., 31, 2441-2448.

VLASKOVSKA M., HERTTING G., KNEPEL W., 1984. Adrenocorticotropin and $\beta$-endrophin release from rat adenohypophysis in vitro: inhibition by prostaglandin formed locally in response to vasopressin and corticotropin-releasing factor. Endocrinology, 115, 895-903.

WEHRENBERG W. B., BAIRD A., YING S. Y., RIVIER C., LING N., GUILLEMIN R., 1984. Multiple stimulation of the adenohypophysis by combinations of hypothalamic releasing factors. Endocrinology, 114, 1995-2001.

WESTLUND K. N., AGUILERA G., CHILDS G. V., 1985. Quantification of morphological changes in pituitary corticotropes produced by in vivo corticotropin-releasing factor stimulation and adrenalectomy. Endocrinology, 116, 439-445.

WIDMAIER E. P., DALLMAN M. F., 1984. The effects of corticotropin-releasing factor on adrenocorticotropin secretion from perifused pituitaries in vitro : rapid inhibition by glucocorticoids. Endocrinology, 115, 2368-2374.

WINTOUR E. M., BELL R. J., FEI D. T., SOUTHWELLE C., TREGEAR G. W., XIAOMING W., 1984. Synthetic ovine corticotropin-releasing factor stimulates adrenocorticotropin release in the ovine fetus over the last fifth of gestation. Neuroendocrinology., 28, 86-87.

WYNN P. C., AGUILERA G., MORELL J. CATT K. J., 1983. Properties and regulation of high. affinity pituitary receptors for corticotropin-releasing factor. Biochem. biophys. Res. Communic., 110, 602-608. 